\title{
Geographic variation in composition of metazoan parasite infracommunities in Galaxias maculatus Jenyns 1842 (Osmeriformes: Galaxiidae) in southern Chile $\left(38-47^{\circ} \mathrm{S}\right)$
}

Mario George-Nascimento ${ }^{1,2}$, Ruby López-Rodríguez ${ }^{1,3}$ and Konrad Górski ${ }^{1,2,4^{*}}$

\begin{abstract}
Galaxias maculatus is an abundant freshwater fish species in Chilean continental waters where it plays important ecological functions, yet few parasitological records of this species exist in Chile and all of them cover a very limited geographic range. The objective of this study was to assess large scale geographic variation in composition of parasite infracommunities of Galaxias maculatus. Specifically, parasite infracommunities of this species were compared among 11 locations across 9 degrees of latitude and 3 ecosystem types (lake, river and estuary). Most taxa found had been previously reported in Chile and Argentina. However, this is the first report for Tylodelphys sp. in this host in Chile. Furthermore, the cranial parasite Tylodelphys sp. had the highest overall prevalence and abundance compared to other parasite species. Despite the fact that the abundance of Tylodelphys sp. was not significantly correlated with Fulton's condition factor of fish, infected fish seem to have a better body condition compared to uninfected ones. The most important source of variation in composition of infracommunities was the sampling location. Furthermore, fish from lakes have a different composition of parasite infracommunities mainly due to higher abundances of Tylodelphys sp.
\end{abstract}

Keywords: Geographic distribution, Estuary, River, Lake, Parasites

\section{Background}

Puye Galaxias maculatus Jenyns 1842 (Osmeriformes: Galaxiidae) is one of the most widely distributed freshwater fish species in the Southern Hemisphere [1]. In Chile, Galaxias maculatus is widespread and often abundant in rivers of central Chile and Patagonia, where it plays an important ecological role [2,3]. There are several parasitological records for this species in Argentina, Australia and New Zealand [4-7], but just five in Chile

\footnotetext{
* Correspondence: konrad.gorski@uach.cl

${ }^{1}$ Facultad de Ciencias, Departamento de Ecología, Universidad Católica de la Santísima Concepción, Concepción, Chile

${ }^{2}$ Centro de Investigación en Biodiversidad y Ambientes Sustentables (CIBAS), Universidad Católica de la Santísima Concepción, Concepción, Chile Full list of author information is available at the end of the article
}

[8-12] and these covered very limited geographic range (one to three sampling locations in each study). The aim of this study was to assess geographic variation in composition of infracommunities of metazoan parasites of $G$. maculatus in Chile (excluding Myxozoa). This was done by comparison of parasite communities among 11 locations across 9 degrees of latitude and 3 ecosystem types (lake, river and estuary, Fig. 1).

\section{Methods}

One-hundred and sixty-six individuals of G. maculatus were collected during 2013 using a beach seine $(5 \mathrm{~m}$ long, $1.5 \mathrm{~m}$ high and $10 \mathrm{~mm}$ stretched mesh size). The beach seine was hauled over a distance of $10-20 \mathrm{~m}$ in

(c) The Author(s). 2020 Open Access This article is licensed under a Creative Commons Attribution 4.0 International License, which permits use, sharing, adaptation, distribution and reproduction in any medium or format, as long as you give appropriate credit to the original author(s) and the source, provide a link to the Creative Commons licence, and indicate if changes were made. The images or other third party material in this article are included in the article's Creative Commons licence, unless indicated otherwise in a credit line to the material. If material is not included in the article's Creative Commons licence and your intended use is not permitted by statutory regulation or exceeds the permitted use, you will need to obtain permission directly from the copyright holder. To view a copy of this licence, visit http://creativecommons.org/licenses/by/4.0/. 


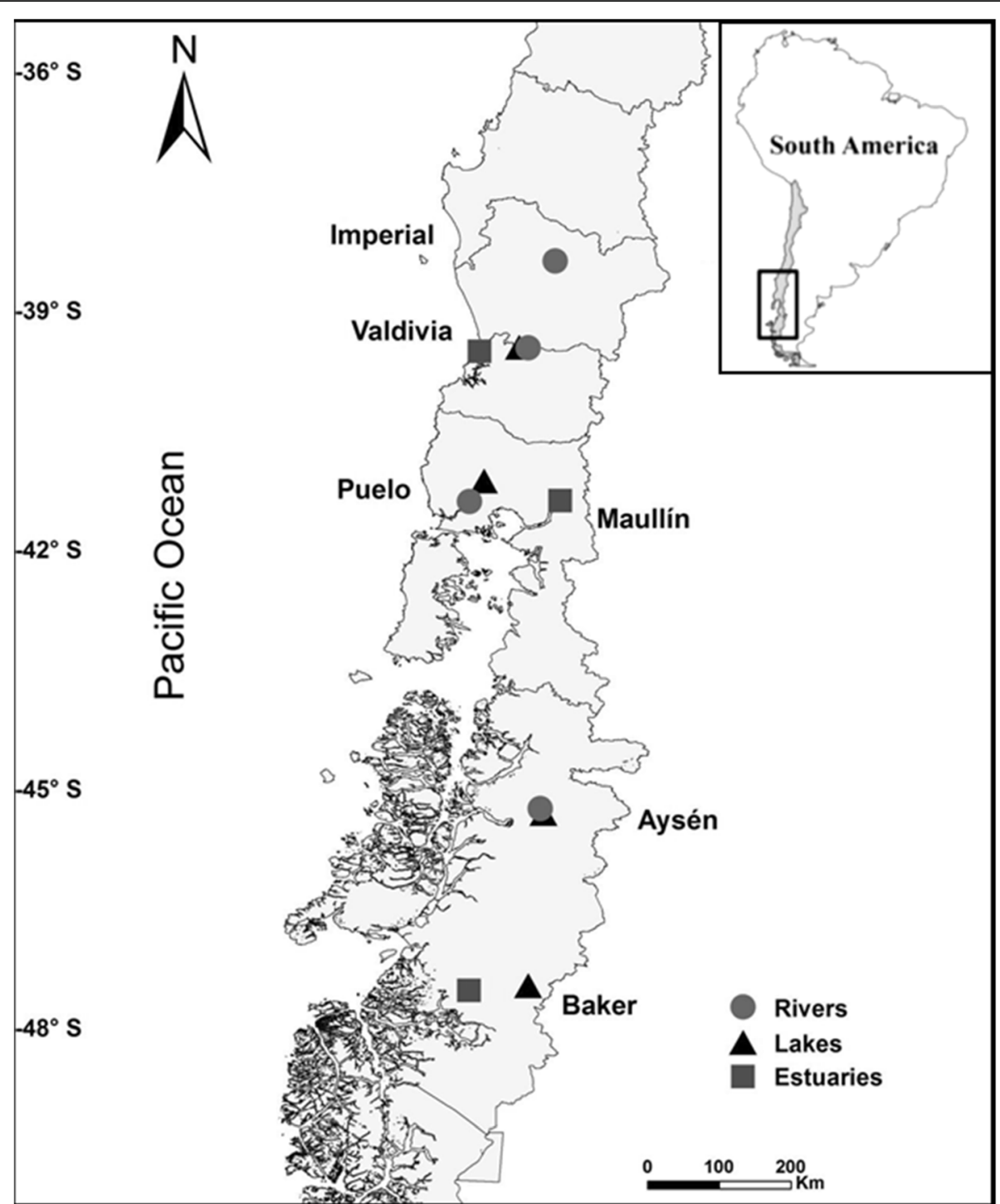

Fig. 1 The study area indicating fish sampling locations and ecosystems (rivers, lakes and estuaries)

the following river basins in southern Chile (Fig. 1: Imperial (river, $38^{\circ} 44^{\prime} 52.42^{\prime \prime} \mathrm{S}, 73^{\circ} 24^{\prime} 27.19^{\prime \prime O}$ ), Valdivia (lake, river and estuary, $39^{\circ} 51^{\prime} 55.33^{\prime \prime} \mathrm{S}, 73^{\circ} 21^{\prime} 21.89^{\prime \prime} \mathrm{O}$ ), Maullín (lake and river, $41^{\circ} 12^{\prime} 38.98^{\prime \prime} \mathrm{S}, 73^{\circ} 2^{\prime} 3.86^{\prime \prime} \mathrm{O}$ ), Puelo (estuary, 41 $39^{\circ} 08.75^{\prime \prime} \mathrm{S}, 72^{\circ} 18^{\prime} 16.78^{\prime \prime} \mathrm{W}$ ), Aysén (lake and river, $45^{\circ} 24^{\prime} 17.87^{\prime \prime} \mathrm{S}, 72^{\circ} 47^{\prime} 41.62^{\prime \prime} \mathrm{W}$ ) and Baker (lake and estuary, $47^{\circ} 47^{\prime} 25.62^{\prime \prime} \mathrm{S}, 73^{\circ} 29^{\prime} 57.42^{\prime \prime} \mathrm{W}$ ). Sample sizes ranged from 6 to 20 host fish per sampling location. Small sample size in some locations was due to low host abundances (catch per unit effort). Each fish specimen was measured (total length, TL; in $\mathrm{mm}$ ) and weighed (total weight, W; in g), then preserved in $70 \%$ ethanol and stored individually. Subsequently, each specimen was thoroughly scraped on the body surface, fins and gills to look for ectoparasites. For endoparasites, we examined eyes, brain, heart, intestine, stomach, liver as well as the cranial and body cavity under a stereomicroscope. Finally, longitudinal cuts were made in the musculature to verify presence of metacercariae.

The variation in TL of G. maculatus among locations and ecosystem types was assessed using general linear models. Subsequently, the size effect was analyzed using partial eta-squared statistic. These analyses were performed in SAS/STAT/PROC GLM software, Version 9.3 (2011). A posteriori tests were run using GT-2 because of unequal sample sizes. The variation in the composition of parasite infracommunities was analysed using permutational multivariate analysis of variance (PERMANOVA) [13] based on fourth-root transformed data and Bray Curtis +1 similarity index. In this analysis, the ecosystem type, sampling locations (nested within ecosystem type) were considered as factors, with total body 
length as covariate. A Principal Coordinates Analysis (PCoA) was used to visually display the distribution of parasite infracommunities among sampling locations and ecosystems using the vectors whose Spearman correlation coefficients were higher than 0.5. Further insight on this ordination was carried out with a One-way ANOVA on the scores of the first PCoA axis with the type of ecosystem as a factor. Furthermore, distance-based test for homogeneity of multivariate dispersions (PERMDISP) was used to compare composition of parasite infracommunities among ecosystems. These analyses were performed in PRIMER statistical program Version 7 [14]. In addition, a Spearman correlation coefficient was used to assess the association between the distances of sampling locations (in $\mathrm{km}$ ) with the similarity in composition of parasite infracommunities. These analyses were performed in XLSTAT $^{\bullet}$ software. Finally, the eventual effect of Tylodelphys sp. on Fulton's condition factor of fishes (a quantitative indicator of host's well-being) was assessed in two ways: by examining the statistical significance of the Spearman correlation coefficient between the abundance of parasites and the condition factor, and by performing a Mann-
Whitney test to compare condition factor of fishes with and without Tylodelphys sp.

\section{Results}

Total length of $166 \mathrm{G}$. maculatus specimens showed medium size effect and significant variations among sampling locations (overall mean \pm S.D. $=3.62 \pm 0.56 \mathrm{~cm}$, $\mathrm{F}_{10,155}=15.04, \mathrm{R}^{2}=0.49, P<0.0001$, size effect partial eta-squared $90 \%$ confidence limits $=0.37-0.54$ ). Specifically, the mean TL of specimens of the small sample from Puelo Estuary $(n=6)$ differed from other locations. Furthermore, fish collected from the Baker River basin (Lbak) were the smallest (Table 1). TL size effect showed significant though small variations among ecosystems (F 2, $163=4.13, P=0.018, \mathrm{R}^{2}=0.049$, size effect partial etasquared $90 \%$ confidence limits $=0.00-0.10$ ). More specifically, fish from rivers were larger than those from lakes (GT-2 Test, $P<0.05$ ).

Sixty-four percent of the specimens harbored at least one parasite. A total of 12 metazoan taxa of parasites was recorded. Most taxa had low prevalence and abundance, except for a diplostomulum type larva found free (unencysted) in the meningeal space (overall prevalence $=49 \%$ ). This parasite accounted for $89 \%$ of all 1214

Table 1 Number of fish examined, total length ( $\mathrm{mm}$ ), weight $(\mathrm{g})$ standard deviation, and number of parasites per sampling location and taxon. Total number of taxa per location (last row) and total number of parasites per location as well as the range of locations in which each taxon occur (right column)

\begin{tabular}{|c|c|c|c|c|c|c|c|c|c|c|c|c|c|}
\hline Sampling location & Ebak & Epue & Eval & Lays & Lbak & Lmau & Lval & Rays & Rimp & Rmau & Rval & & \\
\hline $\mathrm{N}$ fishes examined & 15 & 6 & 15 & 15 & 15 & 6 & 22 & 20 & 20 & 19 & 13 & & \\
\hline Total length (mm) & 37 & 44 & 32 & 37 & 27 & 36 & 36 & 32 & 40 & 46 & 32 & & \\
\hline Standard deviation (mm) & 1,1 & 1,5 & 3,9 & 2,1 & 3,8 & 2,4 & 4,2 & 3,5 & 5,7 & 8,9 & 2,4 & & \\
\hline Weight (g) & 0,27 & 0,59 & 0,32 & 0,53 & 0,18 & 0,56 & 0,49 & 0,32 & 0,56 & 0,55 & 0,33 & & \\
\hline Standard deviation (g) & 0,17 & 0,14 & 0,11 & 0,13 & 0,11 & 0,14 & 0,13 & 0,10 & 0,18 & 0,09 & 0,07 & & \\
\hline Parasite taxa $(\mathrm{si} ; \mathrm{S})^{\mathrm{a}}$ & & & & & & & & & & & & $\mathrm{N}$ parasites & N locations \\
\hline Argulus sp. $(\mathrm{sk}, \mathrm{f} ; \mathrm{A})$ & 0 & 0 & 1 & 0 & 2 & 0 & 0 & 0 & 10 & 24 & 0 & 37 & 4 \\
\hline Dactylogyridae gen. sp. (g; A) & 0 & 0 & 0 & 0 & 0 & 3 & 7 & 6 & 1 & 1 & 0 & 18 & 5 \\
\hline Camallanus corderoi $(\mathrm{i} ; \mathrm{L})$ & 0 & 2 & 0 & 0 & 0 & 1 & 0 & 0 & 0 & 0 & 0 & 3 & 2 \\
\hline Cystidicoloides sp. (s; A) & 0 & 1 & 0 & 0 & 0 & 0 & 1 & 0 & 1 & 1 & 0 & 4 & 4 \\
\hline Contracaecum sp. (m, bc; L) & 2 & 1 & 0 & 0 & 1 & 5 & 0 & 0 & 20 & 3 & 0 & 32 & 6 \\
\hline Tylodelphys sp. (cc; L) & 7 & 140 & 36 & 9 & 472 & 148 & 68 & 5 & 151 & 0 & 48 & 1084 & 10 \\
\hline Posthodiplostomum sp. (i, s; L) & 0 & 0 & 0 & 0 & 0 & 1 & 0 & 0 & 1 & 0 & 0 & 2 & 2 \\
\hline Achanthostomoides apophalliformis (bc; $\mathrm{L})$ & 0 & 0 & 0 & 0 & 1 & 0 & 1 & 0 & 0 & 0 & 0 & 2 & 2 \\
\hline Metacercaria A. apophalliformis (I; M) & 0 & 2 & 0 & 0 & 0 & 6 & 2 & 0 & 0 & 0 & 0 & 10 & 3 \\
\hline Allocreadium pichi (i; A) & 0 & 0 & 0 & 0 & 0 & 9 & 0 & 0 & 0 & 0 & 0 & 9 & 1 \\
\hline Larva Cyclophyllidea (i; L) & 1 & 0 & 0 & 0 & 0 & 1 & 0 & 0 & 3 & 0 & 0 & 5 & 3 \\
\hline Acanthocephalus sp. (i; A) & 4 & 0 & 0 & 4 & 0 & 0 & 0 & 0 & 0 & 0 & 0 & 8 & 2 \\
\hline Total & 14 & 146 & 37 & 13 & 476 & 174 & 79 & 11 & 187 & 29 & 48 & 1214 & \\
\hline $\mathrm{N}$ taxa & 3 & 5 & 2 & 2 & 4 & 8 & 5 & 2 & 7 & 4 & 1 & & \\
\hline
\end{tabular}

${ }^{a}$ si site of infection, $i$ intestine, $c c$ cranial cavity, $g$ gills, $m$ mesenteries, $f$ fins, $b c$ body cavity, $/$ liver, $s$ stomach, sk skin

$S$ Stage, A Adult, L Larva, M Metacercaria 
Table 2 Summary of PERMANOVA of the composition of metazoan parasite infracommunities in $166 \mathrm{G}$. maculatus according to their total length (TL), type of ecosystem (Ec) and sampling location (Lo)

\begin{tabular}{lllllll}
\hline Source & d.f. & SS & MS & Pseudo-F & P (perm) & Perms \\
\hline Total length & 1 & 5384 & 5384,1 & 1134 & 0,340 & 999 \\
Ecosystem & 2 & 4759 & 2379,5 & 0,282 & 0,956 & 998 \\
Lo(Ec) & 8 & 61,025 & 7628,2 & 13,648 & 0,001 & 998 \\
TLx Ec2 & & 540 & 269,8 & 0,483 & 0,822 & 999 \\
TL x Lo(Ec) & 8 & 4407 & 550,9 & 0,986 & 0,469 & 997 \\
Residuals & 144 & 80,485 & 558,9 & & & \\
Total & 165 & $1566 E+05$ & & & & \\
\hline
\end{tabular}

parasitic individuals collected, and was the most prevalent and widespread parasite across locations (Table 1). This parasite was determined as Tylodelphys sp., in the absence of molecular confirmation. However, it is morphometrically similar to Tylodelphys barilochensis Quaggiotto and Valverde 1992 (Digenea: Diplostomatidae) (14), based on its body length and width (in microns) (body length: average \pm S.D. $=456.3 \pm 126.3$, maximum body width: $127.3 \pm 15.0, n=10$ ). There was no significant correlation between the Fulton's condition factor and the abundance of Tylodelphys sp. $\left(\mathrm{r}_{\mathrm{s}}=-0.196, P=0.081\right)$. However, condition factor of non-infected fish was lower than that of fishes infected with Tylodelphys sp. (MannWhitney $\mathrm{U}$ one-tailed test, $\mathrm{U}=2871, P=0.032$ ).

Multivariate dispersion of parasite infracommunities did not differ among ecosystems (Pseudo-F 2, $163=2.09$, $P($ perm $)=0.188)$. The largest part of the variation was associated with sampling locations (GT-2 test, $P<0.05$, Table 2). Two first axes of the PCoA analysis of the composition of parasite infracommunities accounted for $81.5 \%$ of the variation (Fig. 2). The infracommunities of the Maullín River separated from all other locations, mostly due to the absence of Tylodelphys sp. in this basin. Two other parasite taxa were relatively prevalent: the branchiuran Argulus sp. (mostly found in Maullín River), and the larval nematode Contracaecum sp. The one-way ANOVA on the scores of the first PCoA axis with the type of ecosystem as a factor revealed significant differences in composition of infracommunities in fish coming from lakes $\left(\mathrm{F}_{7}, 158=9.438, P<0.0001\right)$ due to higher abundance of Tylodelphys sp. in lakes than in rivers or estuaries (Table 2). The number of taxa per sampling location ranged from 1 to 8 , and was not correlated with the number of fish examined (Spearman

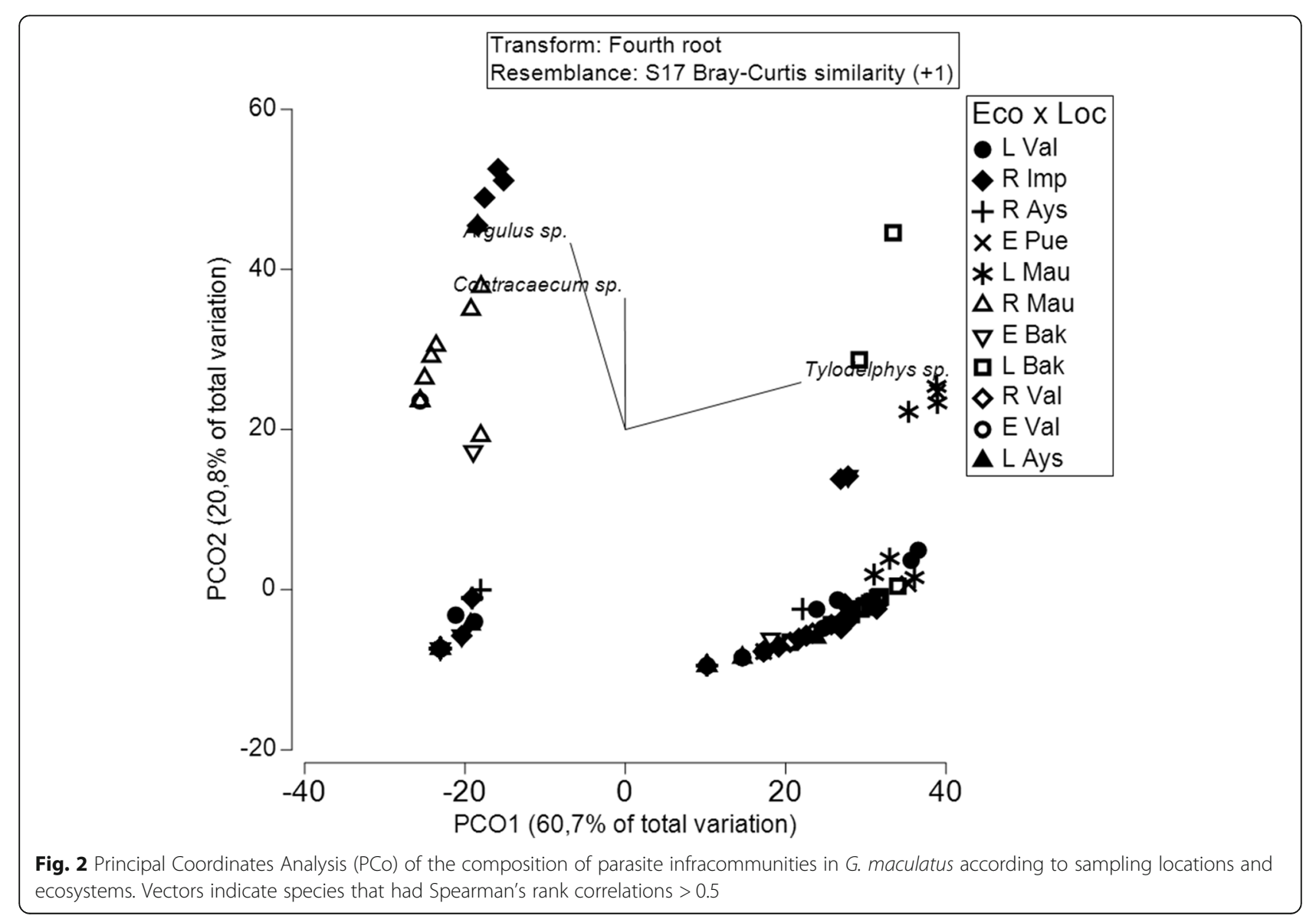


correlation, $\mathrm{r}_{\mathrm{s}}=0.01, n=11, P=0.96$, Table 1$)$. Finally, the distance between sampling locations was not correlated with the similarity of parasite infracommunities (Spearman correlation, $\mathrm{r}_{\mathrm{s}}=0.007, n=55$ pairs of distances between 11 sampling locations, $P=0.55$ ).

\section{Discussion}

This report differs from previous ones in Chile, mainly due the broader geographical range and variety of ecosystems sampled. Previously, the only study on parasites of G. maculatus that considered more than two sampling locations in Chile dealt with Stephanostomum sp. metacercariae only [8]. Another difference of this report is that it is the first carried out at the infracommunity level. Major taxonomic differences found with previous studies was the lack of reports on Tylodelphys sp. for this host in Chile. In neighbouring Argentina, Tylodelphys spp. have been widely reported from several fish species $[5,6,15-19]$. This is also a frequent worm reported for many fish species and places elsewhere (see [20, 21]). Austrodiplostomum mordax Szidat and Nani, 1951 and Tylodelphys destructor Szidat and Nani 1951 were reported in another freshwater fish, Basilichthys australis Eigenmann 1927, from Lake Riñihue in the South of Chile [22, 23]. It is not surprising that fish infected with Tylodelphys sp. show a higher condition factor compared to uninfected fish, as previously reported for other endoparasites in freshwater fish [24]. Furthermore, this better condition is expected to be associated with strategies of transmission to definitive hosts [24].

Differences found in parasite infracommunity composition among sampled locations may be associated with the availability and vagility of intermediate and definitive hosts. For example, the absence of records of Tylodelphys sp. in G. maculatus in Chile may be due to the low abundance of its first intermediate host Chilina dombeyana (Bruguiére, 1789) in some sampling locations. In addition, spatial proximity of sampling locations was not a good predictor of similarity of parasite infracommunities, what has also been shown in other freshwater fish species [25]. With a mixture of larval and adult stages of parasites, there is likely a wide variety of hosts involved in parasite transmission, many of which are invertebrates that have limited dispersal ability, potentially resulting in clumped distributions. Although some results indicated that type of ecosystem was not a relevant factor to account for variations in composition of parasite infracommunities, the ANOVA on the scores of the first PCoA axis revealed that fish from lakes were different to those from rivers and estuaries, mainly due to higher abundances of Tylodelphys sp.. This pattern may be an effect of differential influence of autogenic and allogenic parasite species on patterns of parasite distribution and community composition $[26,27]$.

\begin{abstract}
Abbreviations
ANOVA: Analysis of variance; Ec: Ecosystem; GLM: Procedure uses the method of least squares to fit general linear models; GT-2: Performs pairwise comparisons based on the studentized maximum modulus and Sidak's uncorrelated-t inequality; Lo: Locality; PCoA: Principal coordinates analysis; PERMANOVA: Permutational multivariate analysis of variance; PERMDISP: Test for homogeneity of multivariate dispersions; PROC: Procedure; command to run an analysis in SAS; S.D.: Standard deviation; SAS: Statistical Analysis System; online statistical software suite developed by SAS Institute for data management; TL: Total length; W: Weighed; XLSTAT: Data analysis add-in for

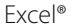

\section{Acknowledgements}

Not applicable.

\section{Authors' contributions}

MG-N analyzed and interpreted the data regarding the composition of infracommunities. RL performed the parasitological examination of the fishes, and was a major contributor to writing of the manuscript. KG sampled the fish and was a major contributor to the writing of the manuscript. All authors read and approved the final manuscript.

\section{Authors' information}

Not applicable.

Funding

Grant CIBAS 2017-1 to MG-N and KG, and Grant Fondecyt 11180545 to KG.

Availability of data and materials

The datasets used and/or analyzed during the current study are available from the corresponding author on reasonable request.

Ethics approval and consent to participate

Not applicable.

\section{Consent for publication}

Not applicable.

\section{Competing interests}

The authors declare that they have no competing interests.

\section{Author details}

${ }^{1}$ Facultad de Ciencias, Departamento de Ecología, Universidad Católica de la Santísima Concepción, Concepción, Chile. ${ }^{2}$ Centro de Investigación en Biodiversidad y Ambientes Sustentables (CIBAS), Universidad Católica de la Santísima Concepción, Concepción, Chile. ${ }^{3}$ Programa de Magister en Ecología Marina, Universidad Católica de la Santísima Concepción, Concepción, Chile. ${ }^{4}$ Instituto de Ciencias Marinas y Limnológicas, Facultad de Ciencias, Universidad Austral de Chile, Valdivia, Chile.

Received: 26 December 2019 Accepted: 24 March 2020

Published online: 09 April 2020

\section{References}

1. González-Wevar CA, Salinas P, Hune M, Segovia NI, Vargas-Chacoff L, Astorga M, Cañete J, Poulin E. Phylogeography in Galaxias maculatus (Jenyns, 1848) along two biogeographical provinces in the Chilean coast. PLoS One. 2015. https://doi.org/10.1371/journal.pone.0131289.

2. Habit E, Piedra P, Ruzzante DE, Walde SJ, Belk MC, Cussac VE, González J, Colin $\mathrm{N}$. Changes in the distribution of native fishes in response to introduced species and other anthropogenic effects. Glob Ecol Biogeog. 2010;19:697-710.

3. Górski K, Habit EM, Pingram MA, Manosalva AJ. Variation of the use of marine resources by Galaxias maculatus in large Chilean rivers. Hydrobiologia. 2018;814(1):61-73.

4. Chapman A, Hobbs RP, Morgan DL, Gill HS. Helminth parasitism of Galaxias maculatus (Jenyns 1842) in southwestern Australia. Ecol Freshw Fish. 2006;15:559-64.

5. Viozzi G, Semenas L, Brugni N, Flores VR. Metazoan parasites of Galaxias maculatus (Osmeriformes: Galaxiidae) from Argentinean Patagonia. Comp Parasitol. 2009;76:229-39. 
6. Fernández V, Garibotti G, Semenas L, Viozzi G. Influence of biotic and abiotic factors on the metazoan parasite communities of a native prey fish: study in 28 Andean Patagonian lakes. Austral Ecol. 2015;25:221-30.

7. Fernández V, Semenas L, Viozzi G. La estructura de las comunidades de helmintos de Galaxias maculatus (Osmeriformes: Galaxiidae) en diferentes sitios de un lago de la Patagonia argentina. Austral Ecol. 2015;25:212-20.

8. Torres P, Franjola R, Cubillos V, Miranda J, Vera R. Parasitism in freshwater ecosystems in Chile. 1. The presence of metacercariae of the genus Stephanostomum (Digenea: Acanthocolpidae) in fish. Zentralbl Veterinarmed B. 1988;35:169-77.

9. Torres P, Contreras A, Cubillos V, Gesche W, Montefusco A, Rebolledo C, Mira A, Arenas J, Miranda JC, Asenjo S, Schlatter R. Parasitismo en peces, aves piscívoras y comunidades humanas ribereñas de los lagos Yelcho y Tagua-Tagua, X región de Chile. Arch Med Vet. 1992;24:77-92.

10. Bravo S, Almonacid C, Oyarzo C, Silva MT. The parasite fauna of Galaxias maculatus in the estuary of Maullín River, Chile. Bull Eur Assoc Fish Pathol. 2007;27:10-7.

11. Torres P, Leyan V, Lamilla J. Cyst stages of Gordiids (Nematomorpha) and other eukaryotic parasites from the Inanga, Galaxias maculatus (Osmeriformes: Galaxiidae), in the Lingue river, Southern Chile. Comp Parasitol. 2017;84:72-9,

12. Vega R, Dantagnan P, Mardones A, Valdebenito I, Zamorano J, Encina F. Bases biológicas para el cultivo del puye Galaxias maculatus (Jenyns, 1842): una revisión. Lat Am J Aquat Res. 2013:41:369-86.

13. Anderson MJ. A new method for non-parametric multivariate analysis of variance. Austral Ecology. 2001;26(1):32-46.

14. Anderson MJ, Gorley RN, Clarke KR. PERMANOVA + for PRIMER: guide to software and statistical methods. Plymouth: PRIMER-E; 2008.

15. Quaggiotto E, Valverde F. Nuevas metacercarias del género Tylodelphys (Trematoda, Diplostomatidae) en poblaciones lacustres de Galaxias maculatus (Teleostei, Galaxiidae). Bol Chile Parasit. 1992;47:19-24.

16. Flores V, Baccalá N. Multivariate analyses in the taxonomy of two species of Tylodelphys Diesing, 1850 (Trematoda: Diplostomidae) from Galaxias maculatus (Teleostei: Galaxiidae). Syst Parasitol. 1998;40:221-7.

17. Revenga J, Scheinert P. Infections by helminth parasites in "puyenes", Galaxias maculatus (Galaxiidae, Salmoniformes), from southern Argentina with special reference to Tylodelphys barilochensis (Digenea, Platyhelminthes). Mem Inst Oswaldo Cruz. 1999;94:605-9.

18. Flores $V$, Semenas L. Larval digenean community parasitizing the freshwater snail, Chilina dombeyana (Pulmonata: Chilinidae) in Patagonia, Argentina, with special reference to the notocotylid Catatropis chilinae. J Parasitol. 2008;94:305-13.

19. Fernández V, Semenas L, Viozzi G. Parasites of the "Peladilla," Aplochiton zebra (Osmeriformes: Galaxiidae), from Patagonia (Argentina and Chile). Comp Parasitol. 2012;79:231-7.

20. Locke SA, Al-Nasiri FS, Caffara M, Drago F, Kalbe M, Lapierre AR, McLaughlin JD, Nie Overstreet RM, Souza GT, Takemoto RM, Marcogliese DJ. Diversity, specificity and speciation in larval Diplostomidae (Platyhelminthes: Digenea) in the eyes of freshwater fish, as revealed by DNA barcodes. Int I Parasitol. 2015:45:841-55.

21. Blasco-Costa I, Poulin R, Presswell B. Morphological description and molecular analyses of Tylodelphys sp. (Trematoda: Diplostomidae) newly recorded from the freshwater fish Gobiomorphus cotidianus (common bully) in New Zealand. J Helminthol. 2017;91:332-45.

22. Torres P, Franjola R, Montefusco A. Seasonal infection by metacercaria of Diplostomum (Austrodiplostomum) mordax (Szidat and Nani, 1951) and Tylodelphys destructor Szidat and Nani, 1951 in the Chilean silverside, Basilichthys australis Eigenmann, 1927 (Pisces:Atherinidae) in Lake Riñihue. Bol Chile Parasit. 1996;51:15-9.

23. Siegmund I, Franjola R, Torres P. Diplostomatid metacercariae in the brain of silversides from lake Riñihue, Chile. J Wild Dis. 1997;33:362-4.

24. Guidelli G, Tavechio WLG, Takemoto RM, Pavanelli G. Relative condition factor and parasitism in anostomid fishes from the floodplain of the upper Paraná River, Brazil. Vet Parasitol. 2011;177:145-51.

25. Locke SA, McLaughlin JD, Marcogliese DJ. Predicting the similarity of parasite communities in freshwater fishes using the phylogeny, ecology and proximity of hosts. Oikos. 2013;122:73-83.

26. Fernández MV, Brugni NL, Viozzi GP, Semenas L. The relationship between fish assemblages and the helminth communities of a prey fish, in a group of small shallow lakes. J Parasitol. 2010;96:1066-71.

27. Rohde K. Marine parasite diversity and environmental gradients. Cap 6. In: Morand S, Krasnov B, editors. editors The biography of Host-Parasite interactions. Oxford: Oxford University Press; 2010. p. 73-8.

\section{Publisher's Note}

Springer Nature remains neutral with regard to jurisdictional claims in published maps and institutional affiliations.

\section{Ready to submit your research? Choose BMC and benefit from:}

- fast, convenient online submission

- thorough peer review by experienced researchers in your field

- rapid publication on acceptance

- support for research data, including large and complex data types

- gold Open Access which fosters wider collaboration and increased citations

- maximum visibility for your research: over $100 \mathrm{M}$ website views per year

At BMC, research is always in progress.

Learn more biomedcentral.com/submissions 